\title{
Effects of allopurinol and preconditioning on apoptosis due to ischemia-reperfusion on a double jejunum-segment canine model ${ }^{1}$
}

\author{
Efeitos do alopurinol e precondicionamento na apoptose devido a isquemia-reperfusão em \\ duplo segmento de jejuno em cães
}

\author{
Endre Brath', Iren Miko"I , Norbert Nemeth ${ }^{\mathrm{III}}$, Judit Kovacs ${ }^{\mathrm{IV}}$, Katalin Peto ${ }^{\mathrm{V}}$, Istvan Furka ${ }^{\mathrm{VI}}$ \\ ${ }^{1}$ Research performed at the Department of Operative Techniques and Surgical Research, Institute of Surgery, Medical and Health Science Center, \\ University of Debrecen, Hungary. \\ ${ }^{\mathrm{I}} \mathrm{MD}$, Assistant Lecturer, Department of Operative Techniques and Surgical Research, Institute of Surgery, Medical and Health Science Center, \\ University of Debrecen, Hungary. Performing operations and sampling, evaluating results, writing paper. \\ ${ }^{\text {II }}$ MD, CSc, PhD, Full Professor, Head of the Department, Department of Operative Techniques and Surgical Research, Institute of Surgery, Medical \\ and Health Science Center, University of Debrecen, Hungary. Conducting experiment, evaluating results. \\ ${ }^{\text {III }} \mathrm{MD}, \mathrm{PhD}$, Assistant Professor, Head of Research Laboratory, Department of Operative Techniques and Surgical Research, Institute of Surgery, \\ Medical and Health Science Center, University of Debrecen, Hungary. Evaluating results, performing statistics, writing paper. \\ ${ }^{\text {IV }} \mathrm{MD}$, PhD, Associate Professor, Chief Doctor, Department of Pathology, Semmelweis Hospital, Miskolc, Hungary. Examination of histological \\ samples, evaluating results. \\ ${ }^{\mathrm{v}} \mathrm{MD}, \mathrm{PhD}$, Assistant Professor, Department of Operative Techniques and Surgical Research, Institute of Surgery, Medical and Health Science Center, \\ University of Debrecen, Hungary. Assisting operations, evaluating results. \\ ${ }^{V 1} \mathrm{MD}, \mathrm{PhD}$, DSc, Emeritus Professor, Head of Microsurgical Educational and Training Center, Department of Operative Techniques and Surgical \\ Research, Institute of Surgery, Medical and Health Science Center, University of Debrecen, Hungary. Conducting experiment, evaluating results, \\ writing paper.
}

\begin{abstract}
Purpose: To investigate the duration of apoptosis caused by ischemia-reperfusion in the intestine in a new double jejunum-segment model, and to analyze the protective effects of allopurinol or ischemic preconditioning (IPC). Methods: In Experiment I for harvesting the double jejunum-segment model after laparotomy a 30-cm-long jejunum part was selected on mongrel dogs (n=24). End-to-end anastomoses were performed at both ends and in the middle of the jejunum part, creating two equal segments. In one segment ischemia was induced by occluding the supplying vessels, the other segment served as control. Tissue samples for detecting apoptosis were taken at 30th minutes, 1st, 2nd, 4th, 6th, 8th, 12th and 24th hours of reperfusion. In Experiment II using the same model the 4-hour reperfusion time period, allopurinol $(50 \mathrm{mg} / \mathrm{kg})$ pre-treated and IPC ( 3 cycles of $5 \mathrm{x} 1)$ groups ( $\mathrm{n}=5$ per each) were also investigated. Results: In Experiment I the greatest apoptotic activity was detected at the 4th and 6th hour of reperfusion (14.2 \pm 1.31 and $16.3 \pm 1.05$ per visual field at 40x magnification). In Experiment II Using the 4-hour reperfusion time period allopurinol pre-treatment increased the apoptotic activity (10.72 \pm 0.47 per 50 intestinal villi) approximately two-fold than the IPC (6.72 \pm 0.46 per 50 intestinal villi) did $(\mathrm{p}<0.05)$. Conclusions: Apoptotic activity has a characteristic time curve, reaching the highest values between the $4^{\text {th }}$ and $6^{\text {th }}$ hours after 30-minute intestinal ischemia. Ischemic preconditioning seemed to be protective against the morphological changes caused by intestinal ischemia-reperfusion.
\end{abstract}

Key words: Ischemia. Reperfusion. Jejunum. Apoptosis. Allopurinol. Ischemic Preconditioning. Dogs. 


\section{RESUMO}

Objetivo: Investigar a duração da apoptose causada pela isquemia-reperfusão no intestino em um novo modelo de duplo segmento de jejuno e analisar os efeitos protetores do alopurinol ou precondicionamento isquêmico (IPC). Métodos: No experimento I para obter o modelo do duplo segmento de jejuno, após a laparotomia, uma parte de $30 \mathrm{~cm}$ de comprimento de jejuno foi selecionada em cães mestiços $(\mathrm{n}=24)$. Anatomoses T-T foram realizadas em ambas as extremidades no meio do segmento de jejuno, criando dois segmentos iguais. Em um segmento foi induzida isquemia por oclusão dos vasos que o irrigavam e o outro segmento foi usado como controle. Amostras de tecido para detecção da apoptose foram obtidos aos 30 minutos, $1 \mathrm{~h}, 2 \mathrm{~h}, 4 \mathrm{~h}, 6 \mathrm{~h}, 8 \mathrm{~h}, 12 \mathrm{~h}$ e 24 horas de reperfusão. No experimento II usando o mesmo modelo, no tempo de reperfusão de 4 horas, foram investigados dois outros grupos ( $\mathrm{n}=5$ cada) usando precondicionamento com alopurinol (50 mg/kg) e IPC (3 ciclos de 5x1). Resultados: No experimento I a maior atividade de apoptose detectada foi às $4 \mathrm{~h}$ e $6 \mathrm{~h}$ de reperfusão (14,2 $\pm 1,31$ e 16,3 $\pm 1,05$ no campo visual de 40x). No experimento II usando o período de 4 horas de reperfusão o pré-tratamento com alopurinol aumentou a atividade apoptótica $(10,72 \pm 0,47)$ aproximadamente 2 vezes mais do que o IPC $(6,72 \pm 0,46)(p<0,05)$. Conclusões: A atividade de apoptose tem uma curva caractetística, atingindo maiores valores entre a ${ }^{\mathrm{a}}$ e a $6^{a}$ horas após 30 minutos de isquemia intestinal. O precondicionamento isquêmico parece proteger contra alterações morfológicas causadas pela isquemia-reperfusão intestinal.

Descritores: Isquemia. Reperfusão. Jejuno. Apoptose. Alopurinol. Precondicionamento isquêmico. Cães.

\section{Introduction}

Ischemia-reperfusion (I/R) injury of small bowel appears in case of small bowel transplantation, heart and aorta surgical interventions, acute and chronic mesenteric arterial and venous occlusion, during hypovolemic shock, intense trauma, in various forms of vasculitis, and necrotising enterocolitis (in childhood) $)^{1,2}$.

Small intestinal mucosa with a high regenerative capacity is one of the tissues being most sensitive to ischemia-reperfusion injury. Chiu et al. $^{3}$ evaluated the ischemia-reperfusion intestinal injury and classified this process in characteristic histological grades. Similarly to other organs, free radicals play an important role in the pathophysiology of mesenterial I/R injury ${ }^{4-6}$, leading to different type of cell death, such as apoptosis or necrosis ${ }^{7,8}$.

Although the pathophysiology of mesenterial ischemiareperfusion injury has been widely studied $^{8,9}$, it still involves questions without answer. What are the role and process of apoptosis in the pathogenesis of $\mathrm{I} / \mathrm{R}$ injuries in the intestinal wall? When does the apoptosis become active and intensive after the death signal has been started? When does the mucosal damage recover to the normal function? Further questions raised whether ischemic preconditioning or administration of allopurinol (inhibitor of xanthine-oxidase) can be effective to keep the normal apoptotic level and morphological structure. Investigating these questions, we aimed to analyse the duration of presence of apoptosis caused by ischemia-reperfusion injury in the intestinal wall using a double jejunum-segment model in the dogs. The second aim was to investigate the effects of allopurinol and ischemic preconditioning in the same model.

\section{Methods}

\section{Experimental animals}

The experiments were performed on 39 male and female dogs, weighting between $21-25 \mathrm{~kg}$, with the permission issued by the University of Debrecen Committee of Animal Research (UDCAR) (Permission Nr.: 22/1999.).

The animals were kept in standard cages at room temperature of $18-22^{\circ} \mathrm{C}$, and fed with a normal mixed food, water ad libitum, and providing them the freedom of movement according to their demands.

The study included two experiments:

Experiment I. $(\mathrm{n}=24)$ a double-jejunum segment model has been carried out. After 30-minute ischemia the histological analyses were done at the $30^{\text {th }}$ minutes, $1^{\text {st }}, 2^{\text {nd }}, 4^{\text {th }}, 6^{\text {th }}, 8^{\text {th }}, 12^{\text {th }}$ and $24^{\text {th }}$ hours of the reperfusion following-up the presence of apoptosis.

Experiment II. $(\mathrm{n}=15)$ the same model and the same ischemic time was used as in Experiment I, and the histological analyses were done at the $4^{\text {th }}$ hour of the reperfusion comparing the effects of ischemic preconditioning and administration of allopurinol.

\section{Experiment $I$.}

Anesthesia, surgical techniques and experimental groups

Anesthesia was induced and maintained by combined administration of SBH-Ketamin (10\% ketaminum hydrochloricum, 
$10 \mathrm{mg} / \mathrm{kg}$, i.m.) and Primazin (2\% xilazinum hydrochloricum, 1 $\mathrm{mg} / \mathrm{kg}$, i.m.). The operations were performed in sterile conditions at the experimental surgical operating room of our department.

After performing midline laparotomy, a $30-\mathrm{cm}$ long jejunum part was selected. At both ends and in the middle portion of the intestinal loop enterotomies were done blocking the intramural collateral blood flow. Three end-to-end anastomoses were performed to maintain the continuity of the bowel creating two segments for investigation of the I/R injury and for control (Figure 1). The vessels supplying these segments were gently dissected from the surrounding tissues to eliminate connections with the systemic circulation. Then 30-minute ischemia was induced by occluding the vessels of one segment (ischemic segment) using an atraumatic vascular clip. The other segment did not suffer from ischemia (control segment).

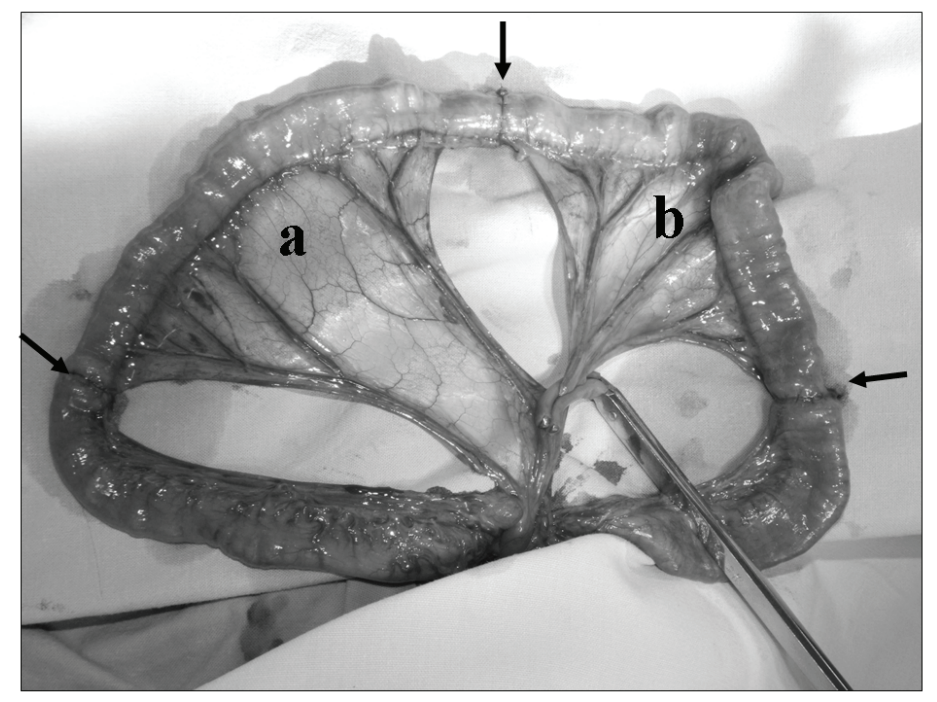

FIGURE 1 - Jejunum segments with 3 intestinal anastomoses. A. Control jejunum segment without clamping. B. Jejunum segment for ischemiareperfusion investigations (The arrows show the intestinal anastomosis).

The animals were divided into 8 groups ( $\mathrm{n}=3$ per each), and accordingly, the tissue samples were taken from the intestine at the $30^{\text {th }}$ minute, $1^{\text {st }}, 2^{\text {nd }}, 4^{\text {th }}, 6^{\text {th }}, 8^{\text {th }}, 12^{\text {th }}$ and $24^{\text {th }}$ hours of the reperfusion, and three parallel examinations per each sample were performed. Also biopsies were taken from the control jejunum segments (Figure 2). During the reperfusion period the abdominal cavity was closed in 2 layers with runing suture lines in all groups except for the 30 minutes group. In this group we closed the abdominal cavity temporary with peritonel clamps. The animals of the 24-hour observation period were allowed to recover from the anesthesia, received analgesics (Demalgonil ${ }^{\circledR}, 1 \mathrm{ml}$ s.c.), and on the next day they were anesthetized again.

At the end of the reperfusion periods macroscopic obrservation of the abdominal cavity, the region of the anastomosis and the lumen of the intestine after opening was carried out.

By the end of the experiments the euthanasia were carried out by giving concentrated potassium-chloride intracardially under general anesthesia for all the animals.

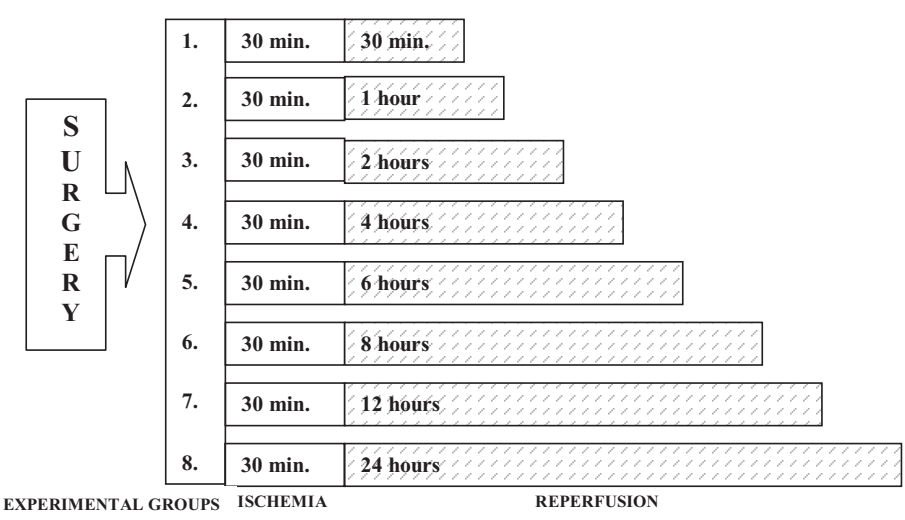

FIGURE 2 - The experimental protocol for investigating apoptosis by different duration of reperfusion after surgery and 30-minute ischemia.

\section{Experiment II.}

Anesthesia, surgical techniques and experimental groups

The anesthesia, operative conditions were the same as in Experiment I. In all animals the double-jejunum segment model has been performed as described above.

Ischemia-reperfusion (IR) group $(\mathrm{n}=5)$ : 30-minute ischemia was induced by atraumatic clamping the vessels that supply the examined, ischemic segment.

Ischemic preconditioning (IPC) group $(\mathrm{n}=5)$ : prior to the 30-minutes ischemia preconditioning protocol was used that included three times performed 5-minutes ischemic period with 1-minute intermittent reperfusion phases.

Allopurinol pre-treated ischemia-reperfusion $(A P+I R)$ group $(\mathrm{n}=5)$ : prior to the 30 -minute ischemia $50 \mathrm{mg} / \mathrm{kg}$ allopurinol (125 $\mathrm{mg}$ in $20 \mathrm{ml} 0.9 \%$ saline solution) was infused into the external jugular vein. Then the ischemia-reperfusion was carried out as in IR group.

In these groups a 4-hour reperfusion period was allowed, while the abdominal wall was closed temporary. At the $4^{\text {th }}$ hour of the reperfusion tissue samples were taken from the ischemic and control jejenum segments for light microscopy and immunohistochemical staining. By the end of the experiment the euthanasia was the same as in Experiment $I$. 


\section{Histological techniques}

Biopsies of the intestinal wall were fixed in $10 \%$ formalin, dehydrated in a graded series of alcohol, embedded in paraffin, microtomed in $5 \mu \mathrm{m}$ step sections, and stained with haematoxilin and eosin (H\&E). Evaluation of the ischemia-reperfusion intestinal injury were performed using the Chiu Scoring System² Grade 0 (G0) - normal mucosa; Grade 1 (G1) - development of subepithelial Gruenhagen's space at the tip of the villus; Grade 2 (G2) - extension of the space with moderate epithelial lifting; Grade 3 (G3) - massive epithelial lifting with a few denuded villi; Grade 4 (G4) - denuded villi with exposed capillaries; and Grade 5 - disintegration of lamina propria, ulceration and hemorrhage.

\section{Immunohistochemical technique}

Apoptotic cells were identified with an in situ apoptosis detection kit using terminal deoxy-nucleotidyl-transferasemediated, dUTP nick end-labeling (TUNEL) assay visualized by direct immunoperoxidase reaction (Apoptag-Kit, Oncor, Biomarker).

In Experiment I, apoptotic index referring to all the positively stained nuclei per visual field at 40x magnification was also calculated. At least 10 visual fields per section were investigated in the histological samples. In Experiment II, the average number of TUNEL positive nuclei per 50 well-oriented villi was calculated both in control and ischemic segments of each group.

\section{Statistical analyses}

Because of the small case number ( 3 animals per time point, 10 visual fields per each tissue sample), in Experiment I a limited comparison was made using one way ANOVA on ranks test (Dunn's method). In Experiment II (5 animals, 50 intestinal villi from each segment) Student's t-test or Mann-Whitney rank sum tests were used according to the data normality tests. A p value $<0.05$ was considered as statistically significant.

\section{Results}

\section{Experiment I \\ Macroscopical observations}

During the experiment there was neither mortality nor any complication in the abdominal cavity and in the operating region. All the intestinal anastomoses functioned well.

After opening the bowel wall we could see that there was a small quantity of debris sticked on the intestinal mucosal surface at the $30^{\text {th }}$ minute, $1^{\text {st }}$ and $2^{\text {nd }}$ hour of reperfusion. At the $4^{\text {th }}, 6^{\text {th }}$ and $8^{\text {th }}$ hours of reperfusion the intestinal lumen was full with debris being and adhered to the intestine wall too. At the $12^{\text {th }}$ and $24^{\text {th }}$ hours of reperfusion there was only a small quantity of debris.

\section{Microscopical investigations}

In accordance with the macroscopical observation, $\mathrm{H} \& \mathrm{E}$ staining demonstrated minimal cellular debris on the intestinal mucosal surface at the $30^{\text {th }}$ minute, $1^{\text {st }}$ and $2^{\text {nd }}$ hour of reperfusion (Figure 3). In numerous villi subepithelial spaces were observed with increased cellularity, mostly of lymphocytes in the apical region. However, the structure of the intestinal wall was well organized (Chiu G2 and G3).

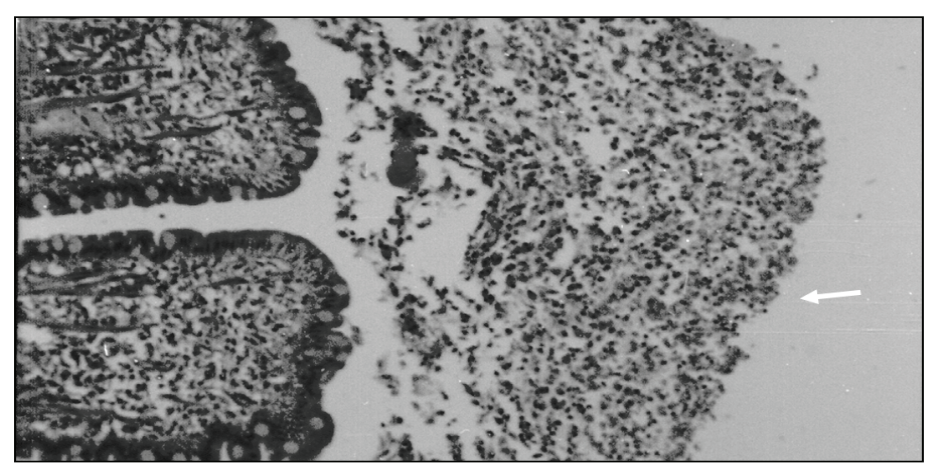

FIGURE 3 - Picture of the mucosa after 30-minute ischemia and 2-hour reperfusion. Arrow shows the large amount of debris on the mucosa surface (H\&E staining, original magnification: 200X).

In the tissue samples taken at the $4^{\text {th }}, 6^{\text {th }}$ and $8^{\text {th }}$ hours of the reperfusion the mucosa was characterized by development of subepithelial Gruenhagen's space, usually at the apex of the villus, often with capillary congestion. In certain villi, extension of the subepithelial space with moderate lifting of epithelial layer from the lamina propria was also observed (G3, G4).

In biopsy materials taken at the $8^{\text {th }}, 12^{\text {th }}$ and $24^{\text {th }}$ hours of the reperfusion there was no damage to the mucosa, and the deeper layers were well organised. Development of subepithelial Gruenhagen's space was very rare (G0-1).

In the control samples mucosa was normal without inflammatory cells (G0). 


\section{Immunohistochemical investigations}

Table 1 shows the number and localization of apoptotic cells (40X magnification).

The control specimens showed healthy structure of mucous membrane and of the deeper layers of the intestinal wall. There was no sign of the inflammation. The apoptotic activity was low: 1-2 apoptotic cells per visual field were located in the bases of the epithelial layer.

The apoptotic activity appeared after 30-minute reperfusion: 3 apoptotic cells per field were detected, both in the basal layer of the mucous membrane and in the apical region of intestinal villi. Also inflammatory cells, mostly lymphocytes were seen.

At the end of the $1^{\text {st }}$ hour of the reperfusion apoptotic cells both in basal and apical areas were observed. Dominantly interstitial but also mucous cells were involved in the process. The numerical value was 3 apoptotic cells per visual field.

In the 2-hour specimens average of 6 apoptotic cells were seen per visual field. Infiltration of inflammatory cells could be seen in the apical region of villi.

TABLE 1 - The number and localization of apoptotic cells in the function of reperfusion time.

\begin{tabular}{ccc}
$\begin{array}{c}\text { Duration of the } \\
\text { reperfusion }\end{array}$ & $\begin{array}{c}\text { The number of the } \\
\text { cells /visual field } \\
\text { at 40x magnification }\end{array}$ & $\begin{array}{c}\text { Localization of the } \\
\text { apoptotic cells in the } \\
\text { intestinal villi }\end{array}$ \\
\hline 0 minute (Control) & $0.7 \pm 0.57$ & basal and apical region \\
\hline 30 minutes & $2.96 \pm 0.61 *$ & basal and apical region \\
\hline 1 hour & $3 \pm 0.74 *$ & basal and apical region \\
\hline 2 hours & $6 \pm 1.17 *$ & apical region \\
\hline 4 hours & $14.2 \pm 1.31 *$ & basal region and in the \\
& & crypts \\
\hline 6 hours & $0.83 \pm 0.59$ & Basal and apical region \\
\hline
\end{tabular}

means \pm S.D.

$* \mathrm{p}<0.05$ vs 0 minutes (Control)
In the $4^{\text {th }}$ hour of reperfusion showed the intestinal lumen was thickly covered with debris containing numerous TUNEL positive cells. However, we proved DNA damage in these cells, we could not count them because the damage might have been caused by necrosis. The average number of apoptotic cells per visual field was 14 , concentrated in the apical region of the villi. However, they also appeared in the basal region, in the crypts, and even in the deeper layers of the intestinal wall (Figure 4).

The apoptotic activity increased progressively in the investigated specimens reaching its peak after 4-6 hours of reperfusion. In the $6^{\text {th }}$ hour of reperfusion we found the highest number of apoptotic cells: 16 TUNEL positive cells were seen per fields.

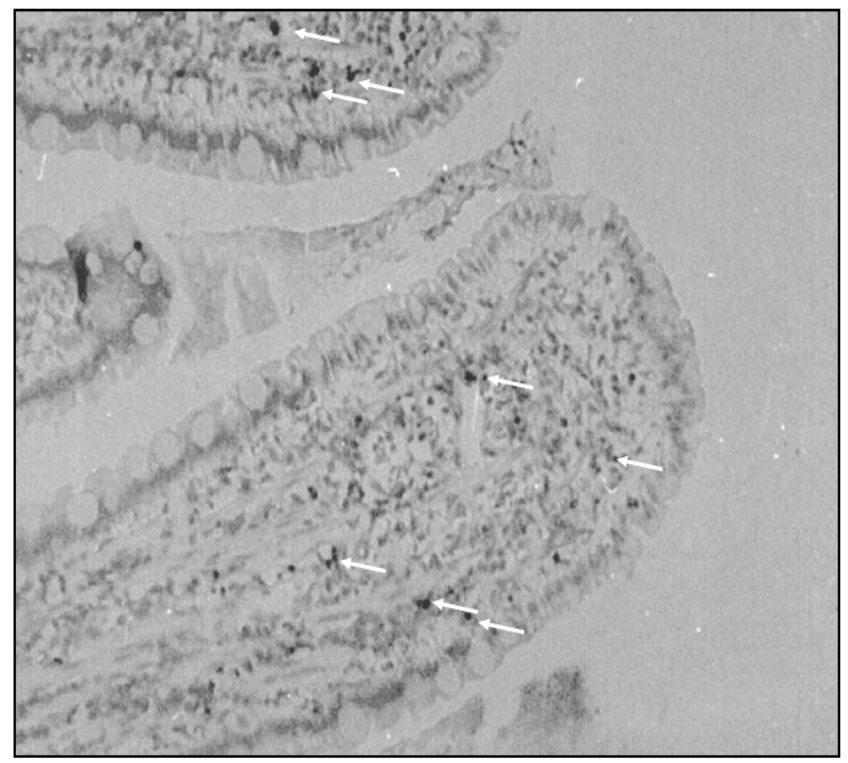

FIGURE 4 - Location of the TUNEL positive cells in the intestinal mucous membrane after 30-minute ischemia and 4-hour reperfusion. The arrow shows a TUNEL positive cell (Apoptag Kit, original magnification: 100X).

In the $8^{\text {th }}$ hour of reperfusion the number of apoptotic cells (placed both apically and basally) dropped to 4 per visual field. However, in the tunica propria there was an extensive inflammatory cell infiltration.

In the 12- and 24-hour specimens the number of apoptotic cells was just like in the control specimens.

\section{Experiment II \\ Macroscopical observations}

Similarly to the relevant results (4-hour) of Experiment I we observed significant amount of cellular debris sticked on the intestinal mucosal surface in each group. In AP+IR group the 
amount of debris seemed to be larger.

\section{Microscopical investigations}

H\&E staining demonstrated the cellular debris on the mucosal surface in all IR, IPC and AP+IR groups, however, the histological grade did not differ between the groups. Each group presented mucosal changes ranging from completely normal apical villi to extension of the space with moderate epithelial lifting (Chiu G0-G2).

\section{Immunohistochemical investigations}

Table 2 shows the number of apoptotic cells in control and ischemic jejunum-segments of IR, AP+IR and IPC groups.

In each group there was significant difference between control and ischemic segment (IR: $\mathrm{p}<0.001$; IPC: $\mathrm{p}=0.008$; $\mathrm{AP}+\mathrm{IR}$ : $\mathrm{p}=0.008$ ). The highest apoptotic activity was observed in AP+IR group, presentig almost two or four-fold difference compared to the IPC or IR group, respectively $(\mathrm{p}<0.001)$. Apoptosis was found to be most intensive at the tip of the villi, however it was present in the deeper layers of the intestinal wall, too.

TABLE 2 - The number of apoptotic cells in mucosal villi of control and ischemic jejunum-segments of IR, AP+IR and IPC groups.

\begin{tabular}{ccc}
\hline $\begin{array}{c}\text { Experimental } \\
\text { groups }\end{array}$ & $\begin{array}{c}\text { Control } \\
\text { segment }\end{array}$ & $\begin{array}{c}\text { Ischemic } \\
\text { segment }\end{array}$ \\
\hline IR & $0.16 \pm 0.09$ & $2.66 \pm 0.82 \#$ \\
\hline IPC & $0.14 \pm 0.05$ & $6.72 \pm 0.46 \# *$ \\
\hline AP+IR & $0.12 \pm 0.04$ & $10.72 \pm 0.47 \# *$ \\
\hline
\end{tabular}

means \pm S.D.

$\mathrm{IR}=$ ischemia-reperfusion; IPC = ischemic preconditioning; $\mathrm{AP}+\mathrm{IR}=$ allopurinol pre-treated ischemia -reperfusion

$* \mathrm{p}<0.05$ vs IR group, \# vs Control segment

\section{Discussion}

The injuries caused by the ischemia-reperfusion originate from many factors, such as reactive oxygen intermediers, leukocyte adhesion molecules, nitrogen oxide ${ }^{10}$. The main source of the free radicals in the intestinal tissue is the xanthine-oxidase/ dehydrogenase system and the activated polymorphonuclear leukocytes. During ischemia the xanthine-dehydrogenase converts to xanthine-oxidase. This process is very fast in intestinal tissue; within one minute of mesenteric ischemia it transforms completely ${ }^{10-12}$. In the hypoxic cell the xanthine-dehydrogenase enzyme - its physiological electronacceptor is $\mathrm{NAD}^{+}$- turns into oxidated form, of which the molecular oxygen is the electron acceptor. At the same time during anoxia the ATP molecule is dephosphorilating in the cell, thus the concentration of AMP is increasing. Therefore in the cells suffering from hypoxia both the xanthine-oxidase and one of its substrate are present. During reperfusion-reoxygenation the other substrate, the molecular oxygen appears and the xanthine-oxidase starts to reduce the molecular oxygen into superoxide radical and hydrogenperoxide ${ }^{12}$. Buttke et $a l .{ }^{13}$ suggested that oxidative stress induces apoptosis, and many of its inhibitors have antioxidant activities or enhance cellular antioxidant defenses.

The intestine contains the highest quantity of these enzymes in the body ${ }^{10}$. Granger et al. $^{12}$ demonstrated that the xanthine-oxidase is presented in the highest quantity and activity in the mucous membrane and in the apical region of the villi, therefore the damage caused by the free radicals are more intensive in this area. These findings may explain, why the histological slides showed so intensive damage in the mucous membrane and why the number of apoptotic cells at the $4^{\text {th }}$ and $6^{\text {th }}$ hour of reperfusion was so high.

It was supposed that the xanthine-oxidase inhibitor allopurinol may reduce the jeopardizing effects of ischemiareperfusion ${ }^{14}$. In our previous models we successfully used the $50 \mathrm{mg} / \mathrm{kg}$ dosage of allopurinol to diminish the hemorheological changes (impairing of red blood cell deformability) of hind limb or renal ischemia-reperfusion injury ${ }^{15,16}$. In current study it was also expected that the number of apoptotic cells together with the necrotic ones decreases ${ }^{13}$. Interestingly, in this jejunum-segment model the allopurinol pre-treated group expressed the highest level of apoptotic activity, and thus, the ratio between necrosis and apoptosis significantly altered in this group. Since significant oxidative stress is known to induce necrosis, it is supposed that the effect of allopurinol might direct the dominant cell death type from necrosis to apoptosis by decreasing the level of reactive oxygen species, and rather increasing the number of apoptotic cells. However, the effect of allopurinol is dose-dependent and supposedly the way of administration would have an influence on the results, too $^{17,18}$.

During ischemia and reperfusion both necrosis and apoptosis may appear depending on the duration and extent of the ischemia. While necrosis is a passive process, the programmed 
cell death, the apoptosis is either an active, gene-regulated process or activation induced. The morphology of apoptotic process caused by ischemia-reperfusion injury in the intestine was firstly published by Shah et al. ${ }^{8}$ : single cell deletion, rounded up apoptotic cells, loose contact with neighbours and condensation or shrinkage, compaction of chromatin forming apoptotic bodies, membrane blebbing without loss of integrity, intact lysosomes, phagocytosis by neighbouring cells or macrophages, and no inflammatory response occurring.

Nicotera et al. ${ }^{19}$ considered the ATP level as a determinative factor in reference to the cells diminishing either in apoptotic or necrotic way. If the intracellular ATP level was low the signal stimulating apoptosis could cause necrosis. The intracellular energy level influences what types of cell-death would eventuate. The conditions determing apoptosis/necrosis are the followings. Apoptosis: ATP shortage of 25-50\%, increased level of $\mathrm{Ca}^{2+} 200-$ $400 \mathrm{nM}$, moderate free-radical formation, activation of caspasesystem is necessary for the process. Necrosis: ATP shortage of $70-100 \%$, increased level of $\mathrm{Ca}^{2+}>1 \mu \mathrm{M}$, large amount of freeradical formation, Bcl-2 activation-free radical production, Bcl-2 inhibition, no activation of caspase-system are required/necessary for the process ${ }^{20}$.

Biochemical events of apoptosis induced by pathological or physiological stimuli are tightly regulated processes by synthetic and activation steps, recquiring energy, macromolecular synthesis and "de novo" gene transcription. One important characteristic of apoptosis appears to be DNA fragmentation ${ }^{20-22}$.

The DNA fragments are formed under the influence of endonuclease activation, an enzyme degrading the DNA at the internucleosomal linker regions ${ }^{22}$.

The enzymes that catalyse this fragmentation are usually non-lysosomal nuclear endonucleases. In certain cells they are activated by $\mathrm{Ca}^{2+}$ and $\mathrm{Mg}^{2+}$ and inhibited by $\mathrm{Zn}^{2+}$. In the mechanism of apoptosis activation of tissue transglutaminase, which appears to produce crosslinking of proteins has possible role to form apoptotic bodies ${ }^{20}$.

In our model the 30-minute ischemia caused morphological changes and injuries characteristically started at intestinal villi and spreaded out down the crypts. There was minimal debris sticked on the mucosal surface from 30 minutes till 2 hours of reperfusion.

It is also well known that apoptosis is a process which demands active protein synthesis that needs time ${ }^{23}$. This could be the reason why the number of apoptotic cells was low at the $30^{\text {th }}$ minute, $1^{\text {st }}$ and $2^{\text {nd }}$ hour of reperfusion, and increased afterwards peaking between the $4^{\text {th }}$ and $6^{\text {th }}$ hours of the reperfusion. The number of apoptotic cells was low at the $8^{\text {th }}, 12^{\text {th }}$ and $24^{\text {th }}$ hour of the reperfusion. It is suggested that the procedure was finished, thus further investigations over these periods of reperfusion time are not appropriate.

This was the reason why in Experiment II we choosed a 4-hour reperfusion period to investigate the protective effect of allopurinol or ischemia preconditioning. Although both procedure showed similar cellular debris on intestinal villi (Chiu Grade 0-2), the allopurinol pre-treatment caused higher apoptotic activity as discussed above. However, ischemic preconditioning resulted in lower number of TUNEL-positive cells compared to allopurinol pre-treatment group.

Ischemic preconditioning by exposing a tissue to a brief period of ischemia followed by reperfusion allowes the ability of the tissue to survive the sustained ischemia ${ }^{24-26}$. In experimental models of mesenterial ischemia, bowel-autotransplantation or jejunal flaps ischemic preconditioning was shown to reduce local acidosis, neutrophil recruitment as well as oxidative stress by complex pathomechanisms ${ }^{26-29}$. Concerning the effective periods of time, Ferencz et al. ${ }^{27}$ found that the nuclear factor $\kappa \mathrm{B}$-related adaptive mechanisms were initiated within 1 hour of ischemic preconditioning and peaking at 3 hours in a canine model of smallbowel autotransplantation. This time period fit well with our observations.

However, the significance of apoptosis in intestinal ischemia-reperfusion still need further studies to clarify the balance or disbalance between apoptotic and necrotic events, and their prevention or treatment.

\section{Conclusions}

Experiment I showed that apoptotic activity has a characteristic time curve, reaching the highest values between the $4^{\text {th }}$ and $6^{\text {th }}$ hours after 30 -minute intestinal ischemia. Thus this period seems to be the most suitable time for investigating the process of apoptosis. Apoptosis was found to be the most intensive at the peak of intestinal villi. In Experiment II the effect of administration of allopurinol was contradictory, but the ischemic preconditioning ( $3 \times 5$ minutes) seems to be suitable protocoll to diminish morphological changes during ischemia-reperfusion injury in this canine model.

\section{References}

1. Abboud B, Daher R, Boujaoude J. Acute mesenteric ischemia after cardio-pulmonary bypass surgery. World $\mathrm{J}$ Gastroenterol. 2008;14(35):5361-70. 
2. Grant D. Current results of intestinal transplantation. Lancet.1996;347(9018):1801-03.

3. Chiu CJ, McArdle AH, Brown R, Scott HJ, Gurd FN. Intestinal mucosal lesion in low-flow states. A morphologic, hemodynamic and metabolic reappraisal. Arch Surg. 1970;101(4):478-83.

4. Linfert D, Chowdhry T, Rabb H. Lymphocytes and ischemiareperfusion injury. Transplant Rev. 2009;23(1):1-10.

5. Cerqueira NF, Hussni CA, Yoshida WB. Pathophysiology of mesenteric ischemia-reperfusion: a review. Acta Cir Bras. 2005;20(4):336-43.

6. Haglund U. Gut ischaemia. Gut. 1994;35(1):S73-6.

7. Azuara D, Sola A, Hotter G, Calatayud L, Oca J. Apoptosis inhibition plays a greater role than necrosis inhibition in decreasing bacterial translocation in experimental intestinal transplantation. Surgery. 2005;137(1):85-91.

8. Shah KA, Shurey S, Green CJ. Apoptosis after intestinal ischemiareperfusion injury. A morphological study. Transplantation. 1997;64(10):1393-7.

9. Berland T, Oldenburg WA. Acute mesenteric ischemia. Curr Gastroenterol Rep. 2008;10(3):341-6.

10. Bradbury AW, Brittenden J, McBride K, Ruckley CV. Mesenteric ischaemia: a multidisciplinary approach. Br J Surg. 1995;82(11):1446-59.

11. Schoenberg MH, Berger HG. Reperfusion injury after intestinal ischemia. Crit Care Med. 1993;21(9):1376-86.

12. Granger DN, Korthuis RJ. Physiologic mechanisms of postischemic tissue injury. Annu Rev Physiol. 1995;57(1):311-32.

13. Buttke TM, Sandstrom PA. Oxidative stress as a mediator of apoptosis. Immunol Today. 1994;15(1):1-4.

14. Perry MA, Wadhwa S, Parks DA, Pickard W, Granger DN. Role of oxigen radicals in ischemia-induced lesion in the cat stomach. Gastroenterology. 1986;90(2):362-7.

15. Nemeth N, Lesznyak T, Szokoly M, Furka I, Mikó I. Allopurinol prevents erythrocyte deformability impairing but not the hematological alterations after limb ischemia-reperfusion in rats. $\mathrm{J}$ Invest Surg. 2006;19(1):47-56.

16. Peto K, Nemeth N, Brath E, Takács EI, Baskurt OK, Meiselman HJ, Furka I, Mikó I. The effect of renal ischemia-reperfusion on hemorheological factors: preventive role of allopurinol. Clin Hemorheol Microcirc. 2007;37(4):347-58.
17. Terzi C, Kuzu A, Aslar AK, Kale IT, Tanik A, Koksoy C. Prevention of deleterious effects of reperfusion injury using one-week highdose allopurinol. Dig Dis Sci. 2001;46(2):430-7.

18. Albuquerque RG, Sanson AJ, Malangoni MA. Allopurinol protects enterocytes from hypoxia-induced apoptosis in vivo. J Trauma. 2002;53(3):415-20.

19. Nicotera P, Leist M, Ferrando-May E. Intracellular ATP, a switch in the decision between apoptosis and necrosis. Toxicol Lett. 1998;102-103(1):139-42.

20. McConkey DJ. Biochemical determinants of apoptosis and necrosis. Toxicol Lett. 1998;99(3):157-68.

21. Grace PA. Ischaemia-reperfusion injury. Br J Surg. 1994;81(5):63747.

22. Cohen JJ. Apoptosis: physiologic cell death. J Lab Clin Med. 1994;124(6):761-5.

23. Coopersmith CM, O'Donnell D, Gordon JI. Bcl-2 inhibits ischemiareperfusion-induced apoptosis in the istestinal epithelium of transgenic mice. Am J Physiol. 1999;276(3):G677-86.

24. Murry CE, Jennings RB, Reimer KA. Preconditioning with ischemia: a delay of lethal cell injury in ischemic myocardium. Circulation. 1986;74(5):1124-36.

25. Walker DM, Yellon DM. Ischaemic preconditioning: from mechanisms to exploitation. Cardiovasc Res. 1992;26(8):734-9.

26. Pasupathy S, Homer-Vanniasinkam S. Surgical applications of ischemic preconditioning. Arch Surg. 2005;140(4):405-9.

27. Ferencz A, Szanto Z, Borsiczky B, Kiss K, Kalmár-Nagy K, Telek G, Szeberényi J, Horváth OP, Röth E. The effects of preconditioning on the oxidative stress in small-bowel autotransplantation. Surgery. 2002;132(5):877-84.

28. Vlasov TD, Smirnov DA, Nutfullina GM. Preconditioning of the small intestine to ischemia in rats. Neurosci Behav Physiol. 2002;32(4):449-53.

29. Unal S, Demirkan F, Arslan E, Cin I, Cinel L, Eskandari G, Cinel I. Comparison of ischemic and chemical preconditioning in jejunal flaps in the rat. Plast Reconstr Surg. 2003;112(4):1024-31.

\section{Correspondence:}

Endre Brath M.D.

Department of Operative Techniques and Surgical Research

Institute of Surgery, Medical and Health Science Center

University of Debrecen

H-4012 Debrecen, POB. 21 Hungary

Phone: +36-52-416-915

e.brath@hotmail.com
Conflict of interest: none Financial source: none
Received: November 10, 2010

Review: January 14, 2011

Accepted: February 15, 2011 